\title{
Phytochemical profile and antimicrobial activity of cashew apple (Anacardium occidentale L.) extract
}

\author{
Laxmanaswami Bhagirathi ${ }^{1}$ and Urooj Asna ${ }^{2, *}$ \\ ${ }^{1}$ Zonal Agricultural and Horticultural Research Station,Brahmavar,Udupi - 576213. \\ ${ }^{2}$ Department of Studies in Food Science and Nutrition, University of Mysore, Manasagangothri, Mysore -570 006, Karnataka, \\ India.
}

Publication history: Received on 01 December 2018; revised on 19 December 2018; accepted on 22 December 2018

Article DOI: https://doi.org/10.30574/gscbps.2018.5.3.0152

\begin{abstract}
Plant phytochemicals have been reported to prolong life by their protections against numerous human health and metabolic conditions. Cashew plant, being a potential source of bioactive compounds, has the ability to ameliorate various lifestyle related diseases. In the present study fruit extracts from Anacardium occidentale L, were analysed for their phytochemical and antibacterial properties. The antibacterial activity of methanol extract of Anacardium occidentale L (cashew apple extract) against Streptococcus pyogenes, Micrococcus luteus, Salmonella typhimurium, Entrococcus faecali and Bacillus cereus were investigated using the agar diffusion method. The result obtained showed that cashew apple extract gave the widest zone of inhibition against one of the five test organisms at the concentration of $1 \mathrm{mg} /$ disk. However, Salmonella typhimurium was more sensitive to the extract. The phytochemical screening indicated the presence of total phenolic content $(405.54 \pm 27.50 \mathrm{mg} / \mathrm{g})$, total flavonoids $(2.378 \pm 0.38 \mathrm{mg} / \mathrm{g})$, and tannins $(33.17 \pm 3.96 \mathrm{mg} / \mathrm{g})$ in the cashew apple extract which confirm its inhibitory activities against the test organisms. This therefore, supports the traditional medicinal use of Anacardium occidentale L in the treatment of bacterial infections.
\end{abstract}

Keywords: Cashew apple; Antibacterial; Antioxidant components; Anacardium occidentale

\section{Introduction}

Traditional medicinal plants have the ability to synthesize a wide variety of chemical compounds that play a major role in primary health care as therapeutic remedies. In addition to this, they serve as alternative sources for western medicines that are expensive, synthetic and as consequence, may have adverse side effects [1]. In our laboratory, various medicinal plants such as Moringa oleifera, Ficus benghalensis, Brassica oleracea and Morus indica (MI) varieties have been screened for their proximate composition, phytochemical profile [2], antioxidant [3], anti-hypercholesterolemic [4], antimutagenic [5], anti-diabetic [6], antimicrobial [7] and protease activities in both in-vitro and ex-vivo models[8].

Anacardium occidentale L. belongs to the family Anacardiaceae. It is one of the most important plantation crops in India, Brazil, Nigeria and Vietnam. However, the edible cashew apple has high nutritive values such as high vitamin C, minerals such as calcium, phosphorus, iron [9]. The cashew apple has found to have several applications in food industries and in breweries. It can be eaten as such and also as juice, pulp, wine [10-11]. Phytochemicals and its biological activities of a plant have been found to be affected by seasonal variation, maturity and environment factors [12]. Although various studies have been carried out on the phytochemical constituents in cashew plants, not much attention has been paid to the variation in the phytochemicals that appear in the different parts especially fruit of these plants. Therefore, the objective of this study was to determine the phytochemical and antibacterial properties of cashew apple extract. This

\footnotetext{
* Corresponding author

E-mail address: asnaurooj@foodsci.uni-mysore.ac.in
} 
will contribute to the knowledge based on the application of these extract as ingredients in developing nutraceuticals and functional foods for the potential treatment against pathogenic bacteria.

\section{Material and methods}

\subsection{Plant material}

Fresh ripe cashew apples from the cashew farm, at the Zonal Agricultural and Horticultural Research Station, Brahmavar, Udupi, Karnataka, India, were picked while harvesting the mature cashew Kernels. Cashew apples were sorted out to remove the blemished and the immature ones. The cashew apples were freeze dried stored at $\left(-20{ }^{\circ} \mathrm{C}\right)$ and used for the analyses of phytochemicals.

\subsection{Chemicals}

Standards viz, Gallic acid, quercetin and ciprofloxacin were purchased from Sigma-Aldrich Chemicals Co. (India). All other chemicals and solvents used were of analytical grade.

\subsection{Preparation of the extract}

The freeze dried cashew apple extract was prepared with slight modification as per the procedure described [7]. Lyophilized sample was macerated with methanol (10 ml/gm of weight) and extracted for 18 hrs before filtration. The fruit sample was re-extracted twice with cold methanol for $4 \mathrm{hrs}$, each time with frequent swirling. The filtrates were mixed, concentrated by drying in oven and was used for further analysis.

\subsection{Quantitative estimation of phytochemicals}

In the dehydrated sample, different phytochemical components were estimated by using standard methods. Total phenols were analyzed by Folin-Ciocalteu micro-method as Gallic acid equivalent [13]. Flavonoid content was determined by a pharmacopoeia method using Rutin as a reference compound [14] and tannins by gravimetric method [15].

\subsection{Antibacterial assay}

The antibacterial activity of cashew apple extract was determined by disc diffusion method [7] against both Grampositive (Streptococcus pyogenes, Micrococcus luteus, Entrococcus faecalis, Bacillus cereus) and Gram-negative (Salmonella typhimurium) bacteria. Each sterile disc $(6 \mathrm{~mm})$ was loaded with $10 \mu \mathrm{l}$ of cashew apple extract (1 mg disc ${ }^{-}$ $\left.{ }^{1}\right)$ and placed at equidistant on nutrient agar plates seeded with test bacteria $\left(1.5 \times 10^{8} \mathrm{CFU} \mathrm{mL}^{-1}\right)$. Ciprofloxacin $(10 \mu \mathrm{g}$ disc $^{-1}$ ) and methanol served as positive and negative controls, respectively. The plates were sealed using para film and incubated at $37 \pm 2{ }^{\circ} \mathrm{C}$ for $24 \mathrm{~h}$ and zone of inhibition was measured.

\section{Results and discussion}

The results of phytochemical screening in the cashew apple powder revealed the presence of various bioactive components such as total phenolic content $(405.54 \pm 27.50 \mathrm{mg} / \mathrm{g})$, Total flavonoids $(2.378 \pm 0.38 \mathrm{mg} / \mathrm{g}) \mathrm{and}$ tannins $(33.17 \pm 3.96 \mathrm{mg} / \mathrm{g})$.

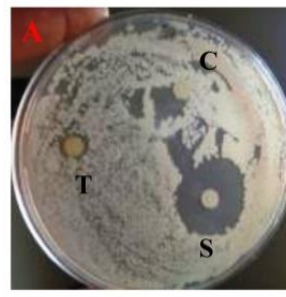

Bacillus cereus

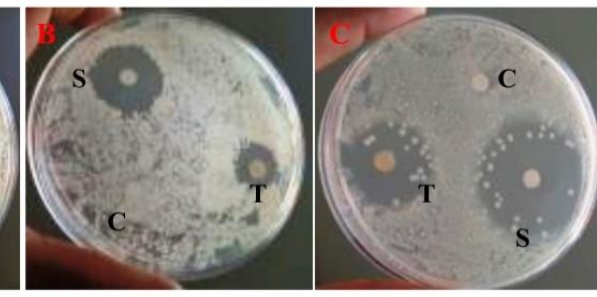

Streptococcus pyogenes

Salmonella typhimurium

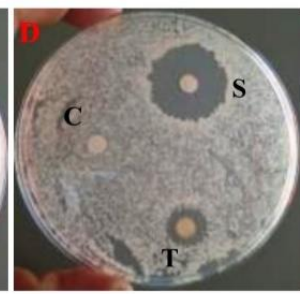

Micrococcus luteus

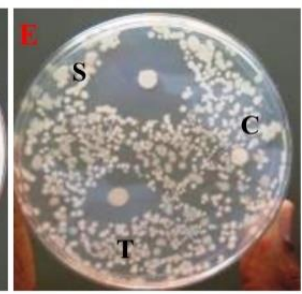

Entrococcus faecalis

Figure 1 Inhibitory activity of cashew apple extract against test pathogens by disc diffusion method T: Test sample-cashew apple extract; S: Standard-Ciprofloxacin; C: Control-Methanol.

The antibacterial activity expressed as inhibition zone diameters of the cashew apple extract at concentrations (1 mg disc $^{-1}$ ) against the against both Gram-positive (Streptococcus pyogenes, Micrococcus luteus, Entrococcus faecalis, Bacillus 
cereus) and Gram-negative (Salmonella typhimurium) bacteria are shown in (Figure 1 and Table 1). It was noted that the extract of $1 \mathrm{mg} \mathrm{disc}^{-1}$ from cashew apple extract offered maximum inhibition zone of $21 \pm 0.35 \mathrm{~mm}$ and $18 \pm 0.3 \mathrm{~mm}$ against the Salmonella typhimurium and Bacillus cereus respectively.

Table 1 Inhibitory activity of cashew apple extract against different pathogenic bacteria

\begin{tabular}{lcc}
\hline \multirow{2}{*}{ Test organisms } & \multicolumn{2}{c}{ Zone of inhibition (mm) } \\
\cline { 2 - 3 } & $\begin{array}{c}\text { Cashew apple extract } \\
\text { (1 } \mathbf{~ g} / \mathbf{d i s c})\end{array}$ & $\begin{array}{c}\text { Ciprofloxacin } \\
\mathbf{( 1 0} \boldsymbol{\mu g} / \mathbf{d i s c})\end{array}$ \\
\hline Streptococcus pyogenes & $13.5 \pm 0.035$ & $22.5 \pm 0.45$ \\
Micrococcus luteus & $11 \pm 0.025$ & $18.5 \pm 0.25$ \\
Salmonella typhimurium & $21.5 \pm 0.25$ & $34 \pm 0.25$ \\
Enterococcus faecalis & $0.9 \pm 0.45$ & $22 \pm 0.45$ \\
Bacillus cereus & $18 \pm 0.35$ & $25.5 \pm 0.35$ \\
\hline
\end{tabular}

In the present study, cashew apple extract was analyzed for phytochemicals and also an attempt was made to check the antibacterial property. Cashew apple extract is found to be a good source of phenolic compounds like polyphenols, flavonoids, and tannin which could be attributed to its potent antibacterial activity. These results are supports with the studies reported on mechanisms of antimicrobial actions of phytochemicals against enteric pathogens [16].

In general, the mechanism of antimicrobial action of phytochemicals may be by inhibiting microbial growth, inducing cellular membrane perturbation, disrupting the proton motive force, coagulation of cell composition and modulation of signal transduction pathways [17]. Flavones are hydroxylated phenolic structures containing one carbonyl group which occur as a C6- C3 unit linked to an aromatic ring. Their activity is probably due to their ability to form complexes with extracellular and soluble proteins as well as the complex with bacterial cell walls, there by inducing microbial cell membrane perturbation [18]. Tannins are polymeric phenolic substances capable of precipitating gelatinous compounds from solution. Tannins were shown to be toxic to filamentous fungi, yeasts, and bacteria and it's used as antiseptic due to presence of the phenolic group [16]. Thus, their mode of antimicrobial action may be related to their ability to inactivate microbial adhesions, enzymes, cell envelope transport proteins [19]. Condensed tannins have been demonstrated to bind cell walls of ruminal bacteria, there by inducing bacterial stasis and protease activity [20]. The results of the present study are also in agreement with the above reports. These findings support the use of the cashew apple extract to protect against bacterial pathogens. These activities of cashew apple extract would provide one of pharmacological backgrounds for its use in folk medicine.

\section{Conclusion}

In conclusion, the presence of various bioactive components in cashew apple extract have been attributed to its potent antibacterial activity. However, Pharmacological investigation should be performed by using advanced technique to discover the potential of the cashew apple extract.

\section{Compliance with ethical standards}

\section{Acknowledgments}

The authors thank the Skanda life sciences laboratory, Bangalore, Karnataka, India, for the facilities extended in conducting the antimicrobial study.

\section{Disclosure of conflict of interest}

The authors declare that there is no conflict of interest.

\section{References}

[1] Onuh J0, Idoko G, Yusufu P and Onuh F. (2017). Comparative studies of the phytochemical, antioxidant and antimicrobial properties of cashew leaf, bark and fruits extracts. American Journal of Food and Nutrition, (4) 115120. 
[2] Reddy VP and Urooj A. (2013). Proximate, phytochemical profile and antioxidant activity (in vitro and ex vivo) of Morus indica varieties. International Journal of Pharmaceutical Sciences and Research, 4(4), 1626-1634.

[3] Satish A, Reddy VP, Sairam S, Ahmed F and Urooj A. (2014). Antioxidative effect and DNA protecting property of Moringa oleifera root extracts. Journal of herbs, spices \& medicinal plants, 20(3), 209-220.

[4] Reddy VP, Urooj A, Sairam S and Ahmed F. (2012). Hypocholesterolemic effect of Moringa oleifera polyphenols in rats fed high fat-cholesterol diet. Malaysian Journal of Nutrition, 3(7), 2510-2516.

[5] Satish A, Kumar RP, Rakshith D, Satish S and Ahmed F. (2013). Antimutagenic and antioxidant activity of Ficus benghalensis stem bark and Moringa oleifera root extract. International Journal of Chemical and Analytical Science, 4(2), 45-48.

[6] Ahmed F, Chavan S, Satish A and Punith KR. (2011). Inhibitory activities of Ficus benghalensis bark against carbohydrate hydrolyzing enzymes-An in vitro study. Pharmacognosy Journal, 3(20), 33-37.

[7] Satish A, Farha Syeda S and Urooj A. (2018). Quantification of flavonoids by UPLC-MS and its antibacterial activity from Brassica oleracea var. Capitata L. GSC Biological and Pharmaceutical Sciences, 5(1), 109-114.

[8] Satish A, Sairam S, Ahmed F and Urooj A. (2012). Moringa oleifera Lam.: Protease activity against blood coagulation cascade. Pharmacognosy Research, 4(1), 44-49.

[9] Vivek MN, Manasa M, Pallavi S, Swamy SH and Prashith KTR. (2013). Antibacterial potential of cashew apple (Anacardium occidentale L.) juice against clinical isolates of Staphylococcus aureus and Streptococcus mutans. Science, Technology and Arts Research Journal, 2(3), 144-146.

[10] Mohanty S,Ray P, Swain MR and Ray RC. (2006). Fermentation of cashew (Anacardium occidentale L.) "apple” into wine. Journal of Food Processing and Preservation, 30, 314-322.

[11] Marc A, Achille TF, Mory G and Koffi PN. (2011). Minerals composition of the cashew apple juice (Anacardium occidentale L.) of Yamoussoukro, Cote D'ivoire. Pakistan Journal of Nutrition, 10(12), 1109-1114.

[12] Ncube B, Finnie JF and Van Staden J. (2011). Seasonal variation in antimicrobial and phytochemical properties of frequently used medicinal bulbous plants from South Africa. South African Journal of Botany, 77(2), 387-396.

[13] Slinkard K and Singleton VL. (1977). Total phenol analysis: automation and comparison with manual methods. American journal of enology and viticulture, 28(1), 49-55.

[14] Anandan S, Kotebagilu NP, Shivanna LM and Urooj A. (2017). Inhibitory potency of C-glycosyl flavonoids from Morus sp. on advanced glycation end products. Journal of Biologically Active Products from Nature, 7(5), 391400.

[15] Makkar HP, Blümmel M, Borowy NK and Becker K. (1993). Gravimetric determination of tannins and their correlations with chemical and protein precipitation methods. Journal of the Science of Food and Agriculture, 61(2), 161-165.

[16] Omojate Godstime C, Enwa Felix, 0, JewoAugustina 0 and Eze Christopher 0. (2014). Mechanisms of antimicrobial actions of phytochemicals against enteric pathogens-a review. Journal of Pharmacy Chemical Biological Sciences, 2(2), 77-85.

[17] Lee H and Lee DG. (2015). Mode of action of bioactive phytochemicals, plant secondary metabolites, possessing antimicrobial properties. The battle against microbial pathogens: Basic science, Technological Advances and Educational Programs. Spain: FORMATEX, 185-92.

[18] Cushnie TT and Lamb AJ. (2005). Antimicrobial activity of flavonoids. International Journal of antimicrobial agents, 26(5), 343-356.

[19] Scalbert A. (1991). Antimicrobial properties of tannins. Phytochemistry, 30(12), 3875-3883.

[20] Jones GA, Mc Allister TA, Muir AD and Cheng KJ. (1994). Effects of sainfoin (Onobrychis viciifolia Scop.) condensed tannins on growth and proteolysis by four strains of ruminal bacteria. Applied and environmental microbiology, $60(4), 1374-1378$.

\section{How to cite this article}

Laxmanaswami B and Urooj A. (2018). Phytochemical profile and antimicrobial activity of cashew apple (Anacardium occidentale L.) extract. GSC Biological and Pharmaceutical Sciences, 5(3), 95-98. 